\title{
Perancangan dan Implementasi Sistem Monitoring Kecepatan Motor BLDC Hub Bergir Pada Sepeda Listrik
}

\author{
Fakih Irsyadi $^{1 *}$, Muhammad Arrofiq ${ }^{2}$, Budi Sumanto ${ }^{3}$, Matthew Sebastian ${ }^{4}$ \\ 1,2,3,4 Universitas Gadjah Mada \\ "fakih.irsyadi@ugm.ac.id
}

\begin{abstract}
Recently, technology development of Electric bike grows fast. The addition of planetary gear is one kind of electric bike driver development. Planetary gear can increase motor output torque. So, for the same (output) torque, motor will be smaller and lighter. In this digital era, electric bike parameter measurement is very important. Not only for research and technology development, the data can also be used to measure performances of the user. One of important parameters on electric bike is speed. Basically, speed measurement can be calculated from wheel speed. In case of BLDC motor, on electric bike driver, the wheel speed measurement can be done by using internal hall sensor. This method can't be used on geared hub BLDC motor. The motor use overrun clutch that can make the wheel freely spin when the motor is not energized. The motor is not spinning even the wheel is mechanically spinning and the output signal of hall sensor is constant. The aim of this research is to propose speed monitoring mechanism for geared hub BLDC motor drive electric bike using external hall effect and reed switch sensor. The result show that the proposed mechanism can accurately measure the dynamic profile of wheel speed with maximum error less than 2,5\%, if we compare with RPM meter with the value of deviation standard less than or equal to $\pm 1,5$ rpm. The proposed mechanism still has good accuracy and precision in spite of the addition of computational load on microcontroller. It indicates that the propose mechanism can be implemented on a complex system.
\end{abstract}

Keywords : e-bike, speed sensor, geared hub BLDC, hall effect, reed speed

\begin{abstract}
Abstrak
Saat ini, teknologi sepeda listrik semakin berkembang pesat. Salah satunya adalah penambahan (planetary) gir pada penggerak jenis hub BLDC. Penambahan ini bertujuan untuk meningkatkan torsi motor, sehingga untuk output torsi yang sama, motor akan lebih kecil dan ringan. Pada era digital ini, pengukuran parameter sepeda listrik sangatlah penting, selain untuk penelitian dan pengembangan teknologi, data pengukuran juga dapat dimanfaatkan untuk mengetahui performansi pengguna saat bersepeda. Salah satu parameter yang sering diukur adalah kecepatan sepeda. Pada dasarnya, pengukuran kecepatan sepeda dapat dilakukan dengan mengukur kecepatan putar roda. Pada sepeda listrik berpenggerak BLDC, pengukuran kecepatan putar roda dapat diakukan dengan memanfaatkan sensor hall effect yang telah tertanam pada motor BLDC. Metode tersebut tidak dapat digunakan pada jenis motor gear hub BLDC. Pada jenis motor ini, terdapat overrun clutch yang menyebabkan roda akan bergerak bebas saat motor tidak diberikan daya. Motor BLDC tidak bergerak meskipun roda secara mekanik bergerak. Akbiatnya tidak terjadi perubahan pada nilai pembacaan sensor hall effect. Pada penelitian ini akan dilakukan perancangan dan implementasi sistem monitoring kecepatan sepeda listrik berpenggerak geared hub BLDC dengan menggunakan sensor hall effect dan reed switch eksternal yang terinspirasi dari prinsip kerja rpm meter digital. Hasil pengujian menunjukkan bahwa sistem monitoring yang dirancang menghasilkan akurasi monitoring serta tingkat presisi yang tinggi, dengan maksimum kesalahan pengukuran kurang dari 2,5\% serta standard deviasi kurang dari sama dengan $\pm 1,5 \mathrm{rpm}$, ketika digunakan pada sistem monitoring kecepatan roda dengan waktu cuplik 0,1 detik. Sistem monitoring tetap menghasilkan akurasi dan presisi pengukuran yang tinggi meskipun kontroler diberikan pembebanan komputasi tambahan. Hal ini menunjukkan bahwa mekanisme yang diusulkan dapat diimplementasikan pada sistem yang lebih kompleks.
\end{abstract}

Kata kunci : listrik, sensor kecepatan, geared hub BLDC, hall effect, reed speed 


\section{Pendahuluan}

Fakta bahwa persediaan minyak bumi di dunia semakin menipis, serta dampak global warming mulai terasa akibat emisi gas rumah kaca yang berlebih, mendorong untuk adanya inovasi pada bidang otomotif. Saat ini dibutuhkan suatu kendaraan yang efisien, aman, nyaman serta ramah lingkungan. Salah satu alternatif teknologi yang ada dan telah dikembangkan saat ini adalah kendaraan listrik. Hingga saat ini masih banyak sekali riset yang dilakukan dalam rangka pengembangan kendaraan listrik, salah satunya adalah sepeda listrik [1].

Jenis motor listrik yang banyak digunakan sebagai penggerak kendaraan listrik adalah motor BLDC [2]. Kemudahan dalam pengendalian kecepatan dan torsi awal yang besar menjadikan BLDC cocok digunakan untuk aplikasi kendaraan listrik. Jika dibandingkan dengan motor brushed DC, motor jenis BLDC mempunyai tingkat efisiensi yang lebih tinggi serta jangka waktu pemakaian yang lebih panjang dikarenakan tidak adanya brush/kontaktor.

Kebutuhan pengukuran serta monitoring parameter sepeda listrik menjadi penting. Selain untuk keperluan penelitian dan pengembangan teknologi, data monitoring juga dapat digunakan sebagai bahan analisis performansi pengguna saat bersepeda.

Saat ini telah banyak perangkat yang secara khusus dikembangkan untuk memenuhi kebutuhan monitoring parameter sepeda yang dapat diaplikasikan untuk sepeda listrik. Beberapa sensor dipasang dan hasil pembacaan sensor dikirimkan ke perangkat electric controller unit (ECU) melalui kabel, maupun nirkabel, untuk diolah dan ditampilkan pada LCD. Pada beberapa perangkat yang lebih canggih, data pembacaan sensor dapat diintegrasikan dengan aplikasi mobile untuk keperluan logging maupun untuk kebutuhan lain.

Salah satu parameter yang sering dipantau adalah kecepatan. Pada dasarnya, terdapat beberapa teknik yang dapat digunakan untuk mengukur kecepatan pada sepeda listrik.
Pada beberapa produk monitoring yang berbasis smartphone, pengukuran jarak dan kecepatan dilakukan dengan memanfaatkan internal GPS yang tersedia. Untuk pengukuran kecepatan sepeda secara real-time, penggunaan GPS tidak direkomendasikan karena tingkat resolusinya yang rendah [3]. Alternatif lainnya adalah dengan mengukur kecepatan putar roda pada sepeda listrik. Untuk roda berpenggerak motor BLDC, pengukuran kecepatan putar roda seringkali dilakukan dengan memanfaatkan hasil pembacaan posisi motor pada sensor hall effect yang telah tertanam pada motor BLDC $[4,5]$.

Untuk sepeda listrik dengan penggerak jenis geared hub BLDC motor, pemanfaatan sensor posisi internal hall sensor teknik tersebut tidak dapat dilakukan. Hal ini disebabkan karena pada konstruksi geared hub BLDC motor, terdapat mekanisme internal overrunning clutch yang menyebabkan roda akan bergerak bebas ketika motor tidak diberikan daya. Pada kondisi ini, rotor tidak bergerak sehingga tidak terjadi perubahan nilai pada sensor hall effect.

Pada dasarnya, penelitian mengenai penggunaan eksternal hall effect sensor untuk menghitung jarak dan kecepatan sepeda telah dilakukan pada penelitian [6]. Pada penelitian ini akan dilakukan perancangan dan implementasi sistem monitoring kecepatan sepeda listrik berpenggerak geared hub BLDC dimana pengukuran kecepatan putar roda dilakukan dengan sensor magnetik pada fork sepeda yang akan mendeteksi keberadaan magnet permanen yang dipasang pada jeruji roda. Kecepatan putar roda ditentukan dari periode deteksi sensor magnetik. Penelitian ini juga akan membandingkan performansi 2 sensor magnetik yaitu sensor hall effect dan sensor reed switch saat digunakan sebagai sensor kecepatan.

Pengujian akan dilakukan dengan dua metode yaitu, tanpa pembebanan dan dengan pembebanan komputasi lain. Beban komputasi yang diberikan adalah simulasi pembacaan sensor arus dan tegangan yang datanya diambil dari potensio (dummy) pada pin ADC. Hal ini 
bertujuan untuk melihat performansi mekanisme pembacaan kecepatan jika diterapkan pada sistem dengan komputasi yang kompleks.

\section{Metoda Penelitian}

Bagian ini akan menjelaskan mengenai komponen utama dalam penelitian serta algoritma yang digunakan untuk menghitung kecepatan roda.

\subsection{Geared Hub BLDC}

Berdasarkan konstruksi penggeraknya, sepeda listrik dibagi menjadi 3 yaitu: [7]

1. Gear

Dimana transfer daya antara penggerak dengan roda dilakukan melalui rantai/sabuk.

\section{2. $H u b$}

Dimana mesin penggerak menyatu dengan hub roda.

\section{Friction.}

Dimana transfer daya antara penggerak dengan roda dilakukan (coupling) secara langsung.

Terdapat 2 jenis motor BLDC hub yang tersedia dipasaran, yaitu, geared hub dan direct drive $h u b$. Jenis geared hub BLDC dilengkapi dengan planetary gear. Gambar 1 menunjukkan konstruksi geared hub BLDC motor yang digunakan pada penelitian ini.
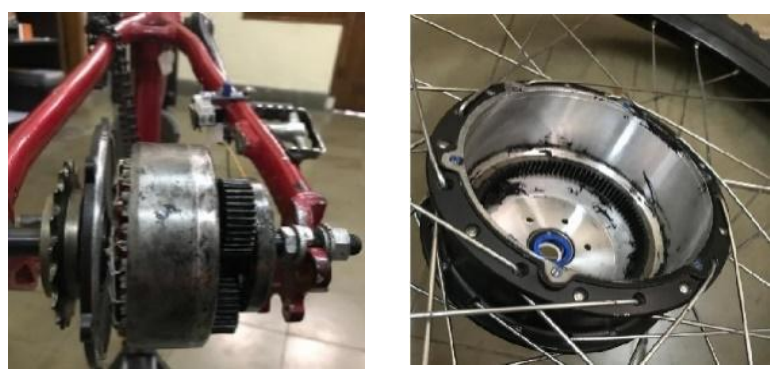

Gambar 1. Konstruksi geared hub BLDC motor

Planetary gear pada BLDC hub meningkatkan torsi motor. Sehingga untuk torsi motor yang sama, geared hub BLDC memiliki dimensi lebih kecil dan ringan dibandingkan dengan jenis Direct drive hub BLDC [8]. Keuntungan lain pada penggunaan geared hub BLDC adalah mempunyai efisiensi yang tinggi pada pengoperasian dengan kecepatan rendah. Penggunaan geared hub BLDC motor sering kali digunakan pada sepeda listrik jenis MTB.

\subsection{Sensor Hall Effect}

Sensor Hall effect adalah sebuah perangkat yang dapat merubah sebuah medan magnet menjadi tegangan listrik. Sensor ini bekerja berdasarkan fenomena efek hall yaitu ketika terdapat arus yang mengalir pada suatu plat logam atau sebuah semikonduktor yang berada pada suatu medan magnet yang tegak lurus, maka akan terjadi gaya Lorenz yang menyebabkan elektron terdorong ke salah satu sisi plat dan menimbulkan tegangan kecil pada yang dapat diukur dari kedua sisi plat [9]. Pada penelitian ini, hall effect sensor digunakan untuk mendeteksi keberadaan magnet permanen yang telah dipasang pada jeruji roda sepeda. Jarak waktu deteksi akan digunakan untuk menghitung kecepatan roda.

\subsection{Sensor Reed Switch}

Sensor reed switch (Magnetic reed switch) adalah saklar listrik yang diopersikan oleh medan magnet. Reed switch terdiri dari 2 plat konduktor tipis berdekatan dan saling tumpang tindih yang terbungkus oleh tabung kaca kedap yang diisi oleh inert gas [10]. Dalam kondisi normal, saklar akan terbuka dan seketika tertutup jika terdapat magnet permanen disekitarnya.

Pada penelitian ini, modul sensor reed switch digunakan untuk mendeteksi keberadaan magnet permanen yang telah dipasang pada jeruji roda sepeda. Jarak waktu deteksi akan digunakan untuk menghitung kecepatan roda.

\subsection{Mekanisme Perhitungan Kecepatan}

Pada dasarnya mekanisme perhitungan kecepatan pada penelitian ini terinspirasi dari prinsip kerja RPM meter digital. Berikut penjelasan mengenai mekanisme perhitungan kecepatan untuk kedua jenis sensor.

\section{a. Penggunaan Sensor Hall Effect}

Secara umum, diagram alir mekanisme perhitungan kecepatan putar roda dengan 
menggunakan sensor hall effect ditunjukkan pada gambar 2. Sensor akan memicu interrupt (hardware) jika mendeteksi magnet. Mikrokontroler akan menghitung jeda waktu deteksi sensor dan mengubahnya menjadi nilai RPM.

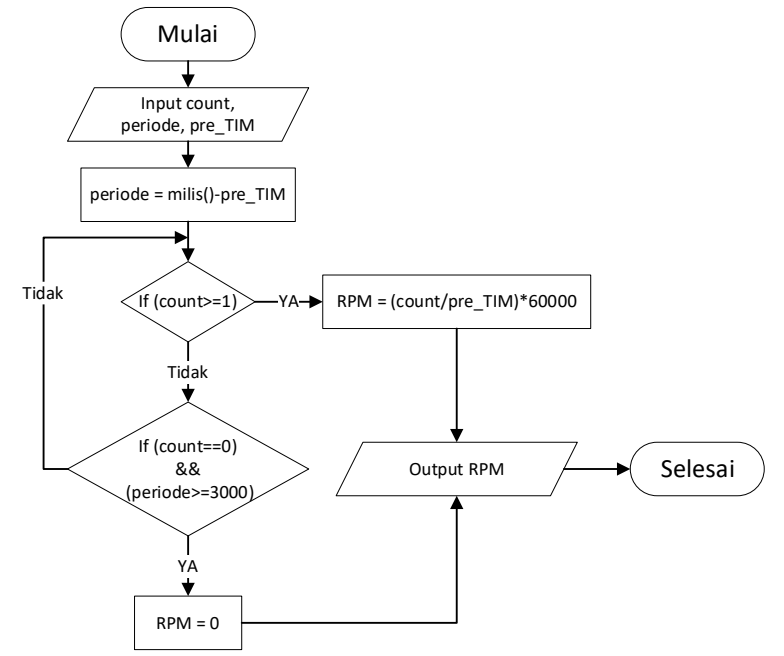

Gambar 2. Algoritma perhitungan kecepatan dengan sensor hall

Nilai RPM akan menjadi nol apabila magnet tidak terdeteksi dalam periode lebih dari 3 detik atau dengan kata lain motor dianggap berhenti berputar.

\section{b. Penggunaan Sensor Reed Switch}

Terdapat sedikit perbedaan pada mekanisme perhitungan kecepatan roda dengan menggunakan sensor reed switch. Penyesuaian algoritma dilakukan untuk mengkompensasi nilai pembacaan pada sensor reed switch. Pada saat pengambilan data, posisi sensor reed switch dipasang secara tegak lurus dengan magnet dan akan mendeteksi sebanyak 2 kali setiap magnet melaluinya. Sehingga perhitungan kecepatan atau RPM dilakukan setiap variabel count bernilai 2 atau lebih serta Nilai RPM akan menjadi nol apabila niali dari variabel count kurang dari sama dengan 1 dalam periode lebih dari 3 detik atau dengan kata lain motor dianggap berhenti berputar.

\section{Hasil Penelitian}

Bagian ini akan menjelaskan mengenai mekanisme pengujian dan pengambilan data serta pembahasan dan analisis data percobaan yang didapat

\subsection{Mekanisme \\ Pengambilan Data}

Pengujian

dan

Seluruh pengujian dilakukan dengan posisi roda sepeda digantung tanpa beban. Proses kalkulasi dan akuisisi data sensor dilakukan dengan menggunakan mikrokontroler Arduino Uno. Secara detail diagram blok pengujian dan pengambilan data dapat dilihat pada gambar 3 sebagai berikut.

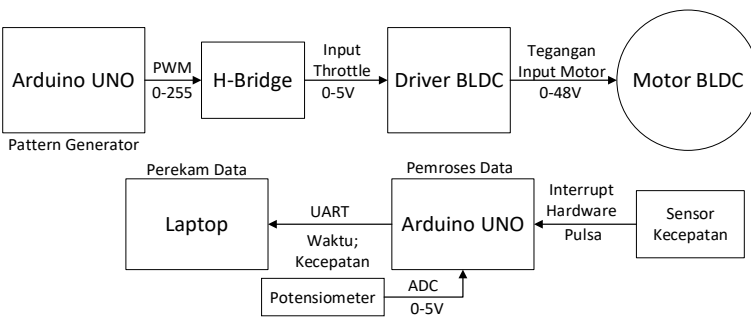

Gambar 3. Diagram blok pengujian dan pengambilan data

\subsection{Validasi Alat Ukur}

Langkah pertama sebelum dilakukan pengujian dan pengambilan data adalah validasi pembacaan sistem. Validasi dilakukan dengan memverifikasi hasil pembacaan kecepatan sistem dengan RPM meter digital dan cycle computer (cat-eye velo 7). Tabel 1 menunjukkan data hasil validasi sensor hall effect pada beberapa nilai kecepatan.

Tabel 1. Hasil validasi sensor kecepatan dengan sensor hall

\begin{tabular}{cccc}
\hline No. & $\begin{array}{c}\text { RPM } \\
\text { Meter }\end{array}$ & $\begin{array}{c}\text { Cycle } \\
\text { Computer }\end{array}$ & $\begin{array}{c}\text { Sensor } \\
\text { Hall }\end{array}$ \\
\hline 1 & 26,3 & 0 & 26,5 \\
2 & 42 & 41,77 & 41,1 \\
3 & 78,4 & 78,72 & 78,2 \\
4 & 63,9 & 64,26 & 63,9 \\
5 & 92,9 & 93,98 & 92,9 \\
6 & 112,5 & 120,49 & 112,5 \\
7 & 153,3 & 155,03 & 153,8 \\
8 & 176,9 & 179,13 & 174,9 \\
9 & 185,3 & 187,97 & 186,9 \\
10 & 201,3 & 202,43 & 201,3 \\
\hline
\end{tabular}

Hasil validasi menunjukkan bahwa hasil pembacaan sistem, dengan sensor hall effect, akurat dengan nilai kesalahan 
maksimumpembacaan sebesar $2,1 \%$ terhadap hasil pembacaan RPM meter.

Tabel 2 menunjukkan data hasil validasi sensor reed switch pada beberapa nilai kecepatan.

Tabel 2. Hasil validasi sensor kecepatan dengan reed switch

\begin{tabular}{cccc}
\hline No. & $\begin{array}{c}\text { RPM } \\
\text { Meter }\end{array}$ & $\begin{array}{c}\text { Cycle } \\
\text { Computer }\end{array}$ & $\begin{array}{c}\text { Reed } \\
\text { Switch }\end{array}$ \\
\hline 1 & 26,7 & 0 & 26,7 \\
2 & 48,9 & 49,80 & 48,9 \\
3 & 56,7 & 57,03 & 56,5 \\
4 & 79,1 & 79,52 & 79,05 \\
5 & 87,4 & 86,75 & 87,4 \\
6 & 119,7 & 120,49 & 119,28 \\
7 & 154 & 154,23 & 154,2 \\
8 & 168,6 & 155,84 & 169 \\
9 & 181,8 & 171,10 & 180,7 \\
10 & 194 & 183,95 & 194,1 \\
\hline
\end{tabular}

Hasil pembacaan sistem, dengan reed switch, akurat dengan nilai kesalahan maksimum pengukuran sebesar $0,6 \%$ terhadap hasil pembacaan RPM meter.

\subsection{Mekanisme Pengujian}

Pada tahap ini, sistem akan memonitoring dinamika perubahan kecepatan roda dengan sampling pembacaan (yang digunakan) adalah 0,1 detik. Pengujian dilakukan dengan dua metode yaitu, tanpa beban komputasi lain dan dengan beban komputasi lain. Beban komputasi yang diberikan adalah simulasi pembacaan sensor arus dan tegangan yang datanya diambil dari potensio (dummy) pada pin ADC. Hal ini bertujuan untuk melihat performansi mekanisme pembacaan kecepatan jika diterapkan pada sistem dengan komputasi yang kompleks. Agar kondisi pengujian kedua sensor serupa, profil dinamika kecepatan dihasilkan dengan memberikan pattern tertentu pada throttle motor listrik yang dihasilkan oleh mikrokontroler eksternal. Profil throttle pengujian ditunjukkan pada gambar 4 sebagai berikut,

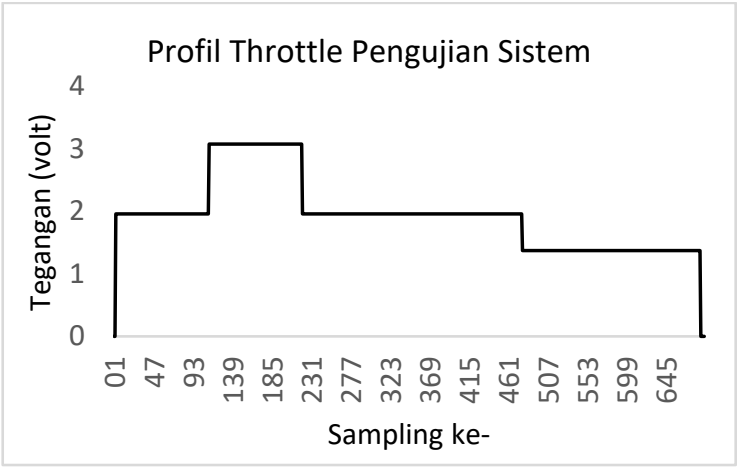

Gambar 4. Profil throttle pengujian sistem

\subsection{Mekanisme Pengolahan Data}

Pada penelitian ini, pengolahan data dilakukan untuk menganalisis akurasi dan presisi sistem yang telah dirancang. Pada penelitian ini, tingkat akurasi sistem dinyatakan dalam nilai kesalahan maksimum hasil pembacaan sistem terhadap pembacaan rpm meter (alat ukur standar) dengan mekanisme perhitungan ditunjukkan pada persamaan (1) sebagai berikut.

$$
\% \text { error }=\frac{\mid \text { standar }- \text { pengukuran } \mid}{\text { standar }} \times 100 \% \ldots
$$

Nilai maksimum error menunjukkan simpangan terjauh hasil pengukuran sistem dengan nilai standar, sehingga, semakin kecil nilainya akan semakin akurat sistem yang digunakan.

Perhitungan tingkat presisi sistem dilakukan dengan menghitung standard deviasi pada sample data hasil pengukuran. Perhitungan nilai standar deviasi dilakukan dengan persamaan (2) sebagai berikut,

$$
s=\sqrt{\frac{\sum_{i}^{n}\left(x_{i}-\bar{x}\right)^{2}}{n-1}}
$$

keterangan:

$$
\begin{aligned}
& x_{i}: \text { data pengukuran; } \\
& \bar{x}: \text { rata - rata pengukuran; } \\
& n: \text { jumlah data. }
\end{aligned}
$$

Nilai standar deviasi menunjukkan seberapa dekat sebaran data pengukuran terhadap rataan seluruh data. Semakin kecil nilai standar deviasi hasil pengukuran 
menunjukkan semakin presisi sistem yang digunakan.

\subsection{Analisis Data Hasil Pengujian}

\subsubsection{Pengujian tanpa Pembebanan}

Pengujian yang pertama dilakukan dengan monitoring dinamika kecepatan sepeda listrik. Pengujian dilakukan tanpa pembebanan komputasi (algoritma) lain sehingga mikrokontroler hanya digunakan untuk monitoring kecepatan. Dalam pengujian ini, dilakukan verifikasi manual pada saat roda sedang berputar dengan kecepatan tetap. Hal ini bertujuan untuk memastikan pembacaan data akurat. Grafik hasil pengujian tanpa pembebanan ditunjukkan pada gambar 5 sebagai berikut.

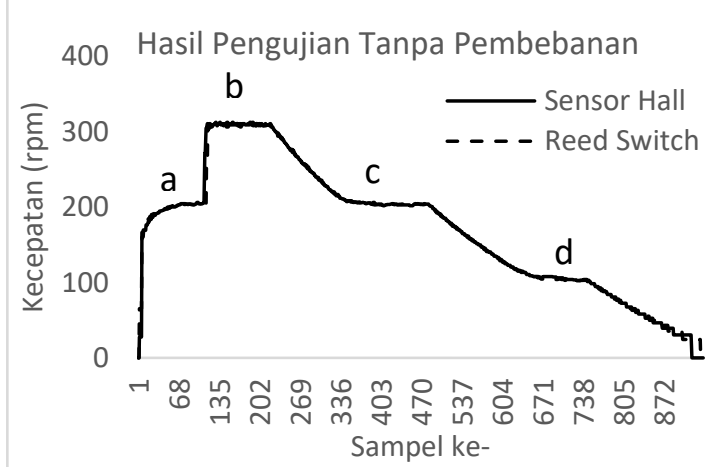

Gambar 5. Grafik hasil pengujian sistem tanpa pembebanan

Dari hasil pengujian pada gambar 5, terlihat bahwa sistem dapat melakukan monitoring dinamika kecepatan roda secara tepat dan akurat dengan time sampling 0,1 detik. Tabel 3 dibawah menunjukkan hasil verifikasi pembacaan sistem untuk setiap nilai kecepatan.

Tabel 3. Tabel keterangan hasil pengujian sistem tanpa pembebanan

\begin{tabular}{ccccc}
\hline Sensor & Titik & $\begin{array}{c}\text { RPM } \\
\text { Meter }\end{array}$ & $\begin{array}{c}\text { Cycle } \\
\text { Computer }\end{array}$ & $\begin{array}{c}\text { Hasil } \\
\text { Pengukuran }\end{array}$ \\
\hline \multirow{4}{*}{ Hall } & a & 204,5 & 204,63 & 203,39 \\
& b & 309,9 & 319,22 & 309,28 \\
& c & 203,1 & 204,63 & 204,78 \\
& d & 103,32 & 139,15 & 104,17 \\
\cline { 2 - 4 } & & & &
\end{tabular}

\begin{tabular}{lllll}
\hline \multirow{4}{*}{ Reed } & $\mathrm{a}$ & 203,4 & 204,6262 & 204,08 \\
& $\mathrm{~b}$ & 308,8 & 311,0318 & 309,28 \\
& $\mathrm{c}$ & 206,2 & 204,6262 & 206,19 \\
& $\mathrm{~d}$ & 103,9 & 106,4056 & 104,17 \\
\hline
\end{tabular}

Dari hasil verifikasi yang ditunjukkan pada tabel 3, terlihat bahwa hasil pengukuran sistem akurat dengan maksimum perbedaan hasil pengukuran pada sistem dengan menggunakan sensor hall effect sebesar 0,82\% dan pada sistem yang menggunakan sensor reed switch $0,33 \%$ terhadap rpm meter. Perhitungan presisi dilakukan pada saat input konstan yaitu pada rentang titik a dan titik c. Hasil perhitungan standar deviasi ditunjukkan pada tabel 4.

Hasil perhitungan standar deviasi, pada tabel 4, menunjukkan bahwa dinamikan hasil pengukuran sangat sempit $< \pm 1,5 \mathrm{rpm}$. Hal ini mengindikasi bahwa sistem yang dirancang presisi.

Tabel 4. Hasil perhitungan standar deviasi percobaan tanpa pembebanan

\begin{tabular}{cccc}
\hline Rentang & Jumlah & \multicolumn{2}{c}{ Standar Deviasi } \\
\cline { 3 - 4 } & Sample & $\begin{array}{c}\text { Sensor } \\
\text { Hall }\end{array}$ & $\begin{array}{c}\text { Reed } \\
\text { Switch }\end{array}$ \\
a & 61 & 1,41 & 1,47 \\
c & 81 & 0,69 & 0,49 \\
\hline
\end{tabular}

\subsubsection{Pengujian dengan Pembebanan}

Pada dasarnya pengujian selanjutnya mempunyai mekanisme yang sama dengan pengujian sebelumnya, hanya saja ditambahkan pembebanan komputasi berupa algoritma lain yang berupa simulasi pembacaan sensor arus dan tegangan yang datanya diambil dari potensio (dummy) di pin ADC. Grafik hasil pengujian dengan pembebanan ditunjukkan pada gambar 6 .

Hasil pengujian pada gambar 6 menunjukkan bahwa sistem dapat melakukan monitoring dinamika kecepatan roda secara tepat dan akurat dengan sampling time sebesar 0,1 detik. Dari hasil pembacaan sistem yang menggunakan sensor reed switch, terdapat 2 data kesalahan pembacaan kecepatan. Hasil observasi menunjukkan kesalahan terjadi pada 
saat hasil deteksi reed switch bernilai lebih dari 2.

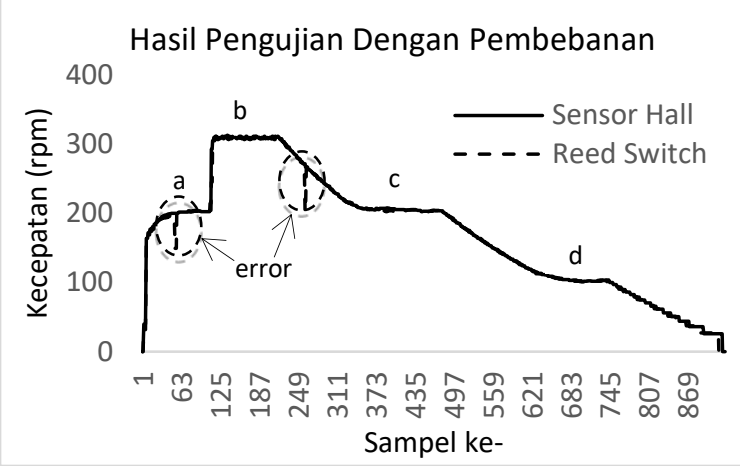

Gambar 6. Grafik hasil pengujian sistem dengan pembebanan

Dugaan sementara, penyebab kesalahan pembacaan ini adalah adanya perubahan posisi sensor saat pengujian akibat getaran atau pergerakan frame sepeda. Tabel 5 menunjukkan hasil verifikasi pembacaan sensor untuk setiap percobaan.

Tabel 5. Tabel keterangan hasil pengujian sistem dengan pembebanan

\begin{tabular}{ccccc}
\hline Sensor & Titik & $\begin{array}{c}\text { RPM } \\
\text { Meter }\end{array}$ & $\begin{array}{c}\text { Cycle } \\
\text { Computer }\end{array}$ & $\begin{array}{c}\text { Hasil } \\
\text { Pengukuran }\end{array}$ \\
\hline \multirow{4}{*}{ Hall } & a & 202,8 & 212,81 & 202,1 \\
& b & 308,9 & 311,03 & 307,69 \\
& c & 203,9 & 212,81 & 206,90 \\
& d & 101,6 & 98,22 & 101,87 \\
\hline \multirow{4}{*}{ Reed } & a & 203,6 & 204,63 & 204,08 \\
& b & 308,5 & 311,03 & 309,28 \\
& c & 202,6 & 204,63 & 203,39 \\
& d & 102,4 & 98,22 & 101,18 \\
\hline
\end{tabular}

Hasil verifikasi, yang ditunjukkan pada tabel 5, menunjukkan bahwa hasil pengukuran sistem akurat dengan maksimum perbedaan hasil pengukuran pada sistem yang menggunakan sensor hall effect sebesar 1,1\% dan pada sistem dengan menggunakan sensor reed switch sebasar 1,4\% terhadap rpm meter.

Perhitungan presisi dilakukan pada saat input konstan yaitu pada rentang titik a dan titik c. Hasil perhitungan standar deviasi ditunjukkan pada tabel 6 sebagai berikut.
Tabel 6. Hasil perhitungan standar deviasi percobaann dengan pembebanan

\begin{tabular}{cccc}
\hline Rentang & Jumlah & \multicolumn{2}{c}{ Standar Deviasi } \\
\cline { 3 - 4 } & Sample & Sensor & Reed \\
& & Hall & Switch \\
a & 61 & 1,27 & 1,27 \\
c & 81 & 0,92 & 0,96 \\
\hline
\end{tabular}

Hasil perhitungan standar deviasi, pada tabel 5, menunjukkan bahwa dinamikan hasil pengukuran sangat sempit $< \pm 1,3 \mathrm{rpm}$. Hal ini mengindikasi bahwa sistem yang dirancang presisi. Hasil ini juga mengindikasikan bahwa sistem monitoring kecepatan roda tetap dapat berjalan dengan akurat dan presisi walaupun mikrokontroler dibebani dengan algoritma lain.

\section{Kesimpulan}

Dari hasil pengujian yang telah dilakukan, terdapat beberapa hal yang dapat ditarik menjadi kesimpulan penelitian ini, yaitu:

1. Sistem monitoring kecepatan dengan menggunakan sensor hall effect dan Sensor reed switch mempunyai nilai kesalahan maksimum sebesar $0,82 \%$ dan $0,33 \%$ serta standar deviasi $< \pm 1,5 \mathrm{rpm}$ saat pengujian tanpa pembebanan ketika digunakan pada sistem monitoring kecepatan roda dengan waktu cuplik 0,1 detik.

2. Sistem monitoring tetap akurat dengan nilai kesalahan maksimum sebesar $1,1 \%$ dan $1,4 \%$ serta standar deviasi $< \pm 1,3$ rpm saat pengujian dengan pembebanan. Hal ini menunjukkan potensi pengunaan sistem monitoring kecepatan, yang diusulkan, untuk digunakan pada sistemsistem yang lebih kompleks.

3. Penggunaan sensor hall effect menghasilkan performansi yang lebih baik dibandingkan dengan sensor reed switch khususnya untuk katahanan terhadap perubahan posisi sensor. Sehingga sensor hall effect lebih cocok untuk digunakan pada sistem-sistem yang bergerak. 


\section{Saran}

Beberapa saran yang dapat diberikan untuk pengembangan penelitian salanjutnya antara lain,

1. Perlu dilakukan pengembangan pengujian pembebanan untuk mekanisme akuisisi data lain yang lebih kompleks, seperti pembacaan GPS atau IMU untuk mengetahui performansi sistem.

2. Perlu adanya investigasi dan penanganan kesalahan pembacaan kecepatan pada penggunaan sensor reed switch, baik dengan pengembangan algoritma maupun teknis pemasangan sensor, sehingga meningkatkan feasibilitas penggunaan sensor khususnya pada sistem-sistem yang bergerak.

3. Pengembangan sistem dapat dilakukan kearah smart dan wireless sensor untuk menambah fleksibilitas penggunaan sistem.

\section{Ucapan Terima Kasih}

Penelitian ini dapat berjalan dengan pendanaan dari Hibah Peningkatan Kapasitas Penelitian Dosen Muda UGM tahun anggaran 2020. Penulis juga ingin berterimakasih kepada pembina serta tim teknis yang telah terlibat pada penelitian ini

\section{Daftar Pustaka}

[1] Rakhmawati, R., Irianto, \& Ruwano, F. T. (2019). Implementation of Fuzzy Logic Control for Soft-Starting Method Brushless DC Motor at Electric Bicycle. Proceedings - 2019 International Seminar on Application for
Technology of Information and Communication: Industry 4.0: Retrospect, Prospect, and Challenges, ISemantic 2019, 497-502. https://doi.org/10.1109/ISEMANTIC.2019.888 4281.

[2] Tibor, Balogh, Fed k, Viliam dan Fransti ek urovsk, 2011, Modeling and Simulation of the BLDC Motor in MATLAB GUI, ISIE PP.1403140.

[3] R. Chen, F. Hao, and Z. Fei, "Design of magnetic navigation automatic guided vehicle system," $J$. Phys. Conf. Ser., vol. 1311, no. 1, 2019.

[4] M. R. Djalal and H. HR, "Speed Control Series Dc Motor Using Ant Colony Optimization," Techno (Jurnal Fak. Tek. Univ. Muhammadiyah Purwokerto), vol. 20, no. 2, p. 105, 2019.

[5]A. Padalkar, "Internal Hall Sensors and Hardware Design," pp. 378-381, 2015.

[6] R. Aisuwarya, M. Azmi Riyan, and R. Eka Putri, "Design of Bicycle's Speed Measurement System Using Hall Effect Sensor," J. Phys. Conf. Ser., vol. 1339, no. 1, 2019.

[7]T. Fujie, N. Imabayashi, and S. Ishikawa, "Electric Bicycle.," Natl. Tech. Rep., vol. 26, no. 5, pp. 863-870, 1980.

[8]E. Starschich and A. Muetze, "Comparison of the performances of different geared brushlessDC motor drives for electric bicycles," Proc. IEEE Int. Electr. Mach. Drives Conf. IEMDC 2007, vol. 1, pp. 140-147, 2007.

[9]E. Ramsden, Hall-Effect Sensors: Theory and Applications, 2nd ed. Burlinton: elsavier, 2006.

[10] P. Zhang, "Chapter 3 - Sensors and actuators," in Advanced Industrial Control Technology, P. Zhang, Ed. Oxford: William Andrew Publishing, 2010, pp. 73-116. 